\title{
The development factors of educational environment
}

\author{
Sergey Ilyin ${ }^{1, *}$, Vazgen Keschyan ${ }^{1,2}$ and Mikhail Zharikov ${ }^{1}$ \\ ${ }^{1}$ Moscow Technological Institute, 199334, Moscow, Russia \\ ${ }^{2}$ Plekhanov Russian University of Economics, Moscow, Russia
}

\begin{abstract}
The paper describes the aspects of the augmented reality application development on the base of ARToolkit for Android. The steps consistently used for the augmented reality application development have been considered. The simplest Java-based examples of augmented reality have been discussed.
\end{abstract}

\section{Introduction}

The economic potential of a nation is mainly determined by the level of the population's education as a primary element of the factors of production. Education is the primary source of scientific discoveries and R\&Ds aimed at efficient and intensive working of all industries in the national economy and national economic clusters. It is the quality of education that serves as a basis to form a society's being which influences the mentality of each and every human being. For that reason the local and federal government, top management and professionals in this field of activity need to fully understand and carry out the measures aimed at improving the educational system, which is why we need to take into account the development factors of the educational environment.

The educational environment is one of the newest categories coined in pedagogical literature in the period of the contemporary human development. There is no common approach to defining this term. So to discover the factors of the educational environment's development it is necessary to provide its objective essence. For example, S.K. Bondyreva [1] and A.N. Dzhurinski [4] connect the category educational environment with geographical aspects and understand it as the pedagogical capacity of a region, district, etc. V.G. Bocharova [8], M.M. Plotkina [7] and N.E. Schurkova [11] think that the educational environment is one of the major factors of social education of the next generation. The authors' idea about the issue is to consider both points of view due to the fact that, firstly and obligatory, the educational environment should encompass all districts, regions, towns and cities. Secondly, the pace of accumulation knowledge processes characterizes mostly younger generation, for the largest share of human intellectual potential is being formed until the age of 30 . The authors also see some other attributes of the educational environment, i.e. the integration of all educational system's elements and its immediate interaction with the economic, political and spiritual life of a society.

\section{Research and discussion}

Based on the above opinion, the authors' view is correct in its understanding of the educational environment as a set of conservative (conventional) factors and progressive (contemporary) factors that influence its development (table 1). It is worth noting that both factor groups have a complimentary (additional or supporting) character and not a substitutional (selfexcluding) one due to their dialectical linkages.

Table 1. The factors of the educational environment

\begin{tabular}{|l|l|}
\hline \multicolumn{1}{|c|}{$\begin{array}{c}\text { Conservative } \\
\text { (conventional) }\end{array}$} & \multicolumn{1}{|c|}{$\begin{array}{c}\text { Progressive } \\
\text { (contemporary) }\end{array}$} \\
\hline Physical aspect & $\begin{array}{l}\text { Controlling in the } \\
\text { educational sphere }\end{array}$ \\
\hline Social aspect & $\begin{array}{l}\text { Social management in the } \\
\text { educational sphere }\end{array}$ \\
\hline Psycho-pedagogical aspect & $\begin{array}{l}\text { Innovation management in } \\
\text { the educational sphere }\end{array}$ \\
\hline
\end{tabular}

With reference to the works of S.K. Bondyreva [1], N.M. Borytko [2]. I.A. Lipski and L.E. Sikorskaya [9], N.N. Pavelko [6] and F.V. Sharipov [10] as well as overseas scientists H.-G. Gadamer [3] and D. Meyers [5], the authors define the following elements of the educational environment:

1. The physical aspect is an area of structural identity and interaction of the existing pedagogical systems in accordance with the current and changing environment. The physical aspect of the educational environment shapes its structural identity, its duration, its form or amorphous condition, its volume, its bounded or unbounded conditions, invariant or variable conditions, stable or unstable conditions, its rigidity or lability.

2. The social aspect is characterized of a moral and psychological climate, traditions, style and manner of interpersonal relations. The social aspect of the educational environment is comprised of the by-laws of social development, the level of a civilization's development, a society's history and culture.

Corresponding author: i.sergey777@gmail.com 
3. The psycho-pedagogical aspect is the area of upbringing which is required to solve educational tasks. The psycho-pedagogical aspect is constituted of the elements such as:

1) the bloc of learning and education:

a) organizing the process of learning;

b) monitoring the process of learning;

2) the bloc of learning and methodology:

a) the development and introduction of the educational and methodological materials;

b) methodological assistance;

3) the bloc of science and research:

a) planning and organizing scientific activity and research;

b) analyzing and assessing the efficiency of the scientific activity and research.

The authors understand the meaning of the progressive factors as their having managerial role mechanisms needed for regulating physical, social and psycho-pedagogical aspects of the educational environment under the current business conditions (table 2):

Table 2. The structure of the educational environment's progressive factors

\begin{tabular}{|l|l|}
\hline \multicolumn{1}{|c|}{ Factors } & \multicolumn{1}{|c|}{ Elements } \\
\hline Controlling in education & $\begin{array}{l}\text { Philosophy of income, } \\
\text { controlling cycle, } \\
\text { controlling methodology }\end{array}$ \\
\hline $\begin{array}{l}\text { Social management in } \\
\text { education }\end{array}$ & $\begin{array}{l}\text { Personnel policy, personnel } \\
\text { planning, personnel } \\
\text { marketing }\end{array}$ \\
\hline $\begin{array}{l}\text { Innovation management in } \\
\text { the sphere of education }\end{array}$ & $\begin{array}{l}\text { Innovation, innovative } \\
\text { scientific schools and } \\
\text { scientific approaches to } \\
\text { innovative activity, life } \\
\text { cycle of innovative activity, } \\
\text { infrastructure of innovative } \\
\text { activity, innovation } \\
\text { strategy, international } \\
\text { innovation management }\end{array}$ \\
\hline
\end{tabular}

1. Controlling in the sphere of education. Controlling is closely connected with supporting the management of the educational environment. It is aimed at coordinating the interaction of management systems in the sphere of education and control of their efficiency.

The elements of controlling in the sphere of education include:

1) the philosophy of income. The philosophy of income presupposes:

a) the priority of comparative indicators over the absolute ones at educational institutions;

b) sustainable growth of educational institutions' efficiency indicators;

c) measures to ensure growth of the educational institutions performance indications;

2 ) the cycle of controlling. The cycle of controlling is built up by several managerial actions in the sphere of education. They are:

a) planning indicators of educational institutions' performance through a system of "from the top to the bottom"; b) planning indicators of educational institutions' performance through a system of "from the bottom to the top ";

c) controlling the planned and actual indicators of educational institutions' performance;

d) balancing the discrepancies between the actual and planned indicators of educational institutions' performance;

3) the controlling methodology. The controlling methodology in the sphere of education is ensured by:

a) learning processes;

b) resources and technologies;

c) the elements of management include:

- audit;

- planning;

- control.

Types of controlling in the sphere of education include:

1) strategic controlling. Strategic controlling is controlling aimed at setting goals and finding solutions to tasks of educational institutions;

2) operational controlling. Operational controlling is controlling aimed at doing certain activities to find solutions to tasks for setting the goals of educational institutions.

The purpose of controlling is to ensure the effective performance of educational institutions on a long-term basis.

The tasks of controlling in education include:

1) tasks in the sphere of accounting:

a) developing accounting policy of educational institutions;

b) harmonizing methods to assess educational institutions' performance;

c) finding criteria to assess educational institutions' performance;

d) evaluating the efficiency of primary accounting activities of educational institutions;

e) evaluating the efficiency of synthetic and analytical accounting of educational institutions' activities;

2) tasks in the sphere of planning:

a) developing plans of educational institutions' activities;

b) establishing methods of planning educational institutions' performance indicators;

c) verifying the established plans of the educational institutions to make sure they can be completed and realized;

d) coordinating plans of educational institutions' activities;

e) preparing master plans of educational institutions;

3) tasks in the sphere of control:

a) determining the dynamics and system of controlled indicators of educational institutions activity;

b) establishing allowable limits on the deviations of actual indicators of educational institutions' activities from the planned ones;

c) comparing the actual and planned indicators of educational institutions' activities; 
d) identifying deviations of actual indicators of educational institutions' activities from the planned ones;

e) developing proposals to improve educational institutions' performance;

4) tasks in the sphere of information and analytical support:

a) designing the structure of the information system of educational institutions' activities;

b) providing digital materials to analyze the performance of educational institutions;

c) mobilizing resources for accounting, planning and control of educational institutions' performance indicators;

d) consultancy in issues of taking management decisions to adjust educational institutions' performance indicators;

5) specific tasks of controlling:

a) collecting and analyzing information about the external environment of educational institutions;

b) comparing educational institutions' performance indicators with the organizations' performance in other industries;

c) justifying sales efficiency indicators of certain services' types of educational institutions;

d) justifying efficiency indicators of investment and innovative projects of educational institutions;

e) rationalizing the development of economic ties among educational institutions.

The principles of controlling in education:

1) regulating the dynamics educational institutions' development;

2) recording all business transactions of educational institutions' activities;

3) regular control of educational institutions' activities;

4) flexibility of controlling educational institutions' activities;

5) strategic direction of educational institutions' activities.

The functions of controlling in education include:

1) accounting function;

2) planning function;

3) control function;

4) information and analytical function;

5) commentary function.

The requirements to controlling in education:

1) total compliance to the purpose and tasks of educational institutions;

2) integrity and consistency of information on the activities of educational institutions;

3) the ability to adapt to factors of internal and external environment of educational institutions;

4) reliability;

5) long-term sustainability.

2. Social management in education. Social management in education is a fundamental part of personnel management in the educational environment.

The elements of social management in education:
1) personnel policy. Personnel policy is a set of principles to form the personnel management strategy in educational institutions.

The types of personnel policy in education include:

a) depending on the level of top management influence on the staff we can define the following types of personnel policy in education:

- passive personnel policy which is carried out by the educational institutions' top management who do not have a clear action program in respect to personnel. Here the work with personnel is limited to eliminating negative impact through evaluation and diagnosis of the staffing situation in general;

- reactive personnel policy is carried out by the educational institutions' top management to implement control over symptoms of negative aspects in working with the staff, the causes of conflict situations, lack of motivation to highly productive performance in a situation of ongoing crisis;

- preventive personnel policy is carried out by the educational institutions' top management when they are sure of established forecasts in developing the human resources. In this case they deal not only with the personnel diagnosis, but also with forecasting the midterm personnel situation;

- active personnel policy is carried out by the educational institutions' top management which are able to predict the personnel situation and make decisive actions in cases something goes wrong, and the human resources department is able to develop a long-term personnel program;

b) depending on focusing on the internal or external staff we can define the following types of personnel policy in education:

- open personnel policy which means that workers are accepted in educational institutions both at the lowest position and the position at top management level;

- closed personnel policy which means that workers are accepted into educational institutions at the lowest positions, and vacancies are available only for previously hired employees.

The directions of personnel policy in the sphere of education include:

a) ensuring a high level of labor quality and its results as well as the life in a team;

b) efficient allocation and use of employees as well as optimization of their number;

c) organization of work and workplaces;

d) selection and placement;

e) planning staff numbers;

f) forecasting the amount of new jobs in accordance with the introduction of progressive technologies;

g) development of incentive systems and motivation mechanisms to increase interest and satisfaction at work;

h) rationalizing personnel costs;

i) life security and personnel healthcare;

j) creating programs of personnel development;

2) personnel planning. Personnel planning is a targetoriented activity focused on providing jobs at the right time and in required numbers in accordance with the abilities and aptitudes of employees and the requirements of educational institutions. 
The personnel planning in education includes:

a) personnel strategy;

b) personnel objectives;

c) personnel tasks;

d) personnel measures.

The types of personnel planning in education include:

a) strategic personnel planning. Strategic personnel planning is a long-term plan (on average from 3 to 5 years) associated with setting objectives of personnel planning and relevant performance indicators of educational institutions;

b) tactical personnel planning is a med-term plan (on average from 1 to 2 years) associated with achieving certain tasks for setting the objectives of personnel planning and relevant performance indicators of educational institutions;

c) operational personnel planning is an operational plan (on average a few months) associated with implementing specific actions with certain tasks for setting the objectives of personnel planning and relevant performance indicators of educational institutions.

The stages of personnel planning in education include:

a) analyzing strategic plan activities;

b) forecasting staffing requirements;

c) assessing internal staff;

d) preparing plans to ensure the necessary personnel;

3) personnel marketing.

The levels of marketing personnel in education include:

a) depending on the time frame:

- strategic personnel marketing;

- tactical personnel marketing;

- operational personnel marketing;

b) depending on the sphere of activity:

- internal personnel marketing;

- external personnel marketing.

The stages of social management in education:

a) planning future staffing needs (employees);

b) staff recruitment;

c) selecting the best personnel;

d) determining the volume of remuneration and benefits to staff; staff;

e) professional orientation and adaptation of recruited

f) training of the staff employed;

g) evaluating the staff performance;

h) developing methods of personnel movements to other posts or work sites for the development of their professional experience;

i) termination of the contract with the employed staff.

The purpose of social management is to achieve effective personnel management in education.

The tasks of social management in education:

a) helping educational institutions in achieving their objectives;

b) effective use of the staff accomplishments;

c) organizing highly qualified staff and interest in the work of staff;

d) trying to achieve the full satisfaction of staff with their work; e) developing and maintaining a high quality of life of personnel;

f) ensuring positive labor climate in educational institutions.

3. Innovation management in the sphere of education. Innovation management in the sphere of education is associated with the analysis of the by-laws of implementing innovations in educational environment.

The period of innovation implementation is called the innovation process.

The stages of the innovation process in education include:

1) generating innovative ideas;

2) developing innovative ideas;

3) implementing innovative ideas.

The elements of innovation management in education include:

1) innovation;

2) innovative scientific schools and scientific approaches to innovation activities;

3) life cycle of innovation products;

4) infrastructure of innovation activities;

5) innovation strategy;

6) international innovation management.

The purpose of innovation management is to achieve the effective performance of educational institutions on an intensive basis.

The tasks of innovation management in education include:

1) defining the strategic directions of innovation activity of educational institutions;

2) planning innovation activities of educational institutions;

3) organizing innovation activities of educational institutions;

4) motivating the participants of innovation activities of educational institutions;

5) controlling the participants of innovation activities of educational institutions;

6) systemically assessing the results of innovation activities of educational institutions.

A special role in the period of globalization of economic relations, including education, is taken by international innovation management.

The elements of international innovation management in the sphere of education include:

1) organizing management mechanism of foreign innovation activities of educational institutions;

2) structures of foreign innovation activities of educational institutions;

3) business communication used in implementing foreign innovation activities of educational institutions;

4) factors of implementing foreign innovation activities of educational institutions;

5) functions of the international innovation management of educational institutions:

a) planning foreign innovation activities;

b) organizing foreign innovation activities;

c) motivating foreign innovation activities;

d) controlling foreign innovation activities;

e) monitoring foreign innovation activities. 
The objectives of international innovation management in education include:

1) developing new markets of innovative educational services;

2) incomplete saturation of the markets of innovative educational services;

3) high level of innovation competition in the domestic market of educational services;

4) large amount of internal innovation costs in the market of educational services;

5 ) is not an acceptable level of efficiency of internal innovative activities on the provision of educational services.

The benefits of international innovation management in education include:

1) expansion of innovative activity of educational organizations;

2) ensure the full realization of the innovative potential of educational organizations;

3) total or partial avoidance of educational organizations to internal innovation competition;

4) improvement of educational organizations from conducting their innovative activity;

5) ensuring an acceptable level of efficiency of innovative activity of educational organizations.

The author's proposes are based on the following aspects:

1. To develop the educational environment by integration of conservative and progressive factors for its adaptation to modern economic conditions, characterized by an active interaction of the public and commercial sectors of the national economy.

2. To pay special attention to the modern development trends of educational environment related to globalization processes and advanced scientific and technical achievements, to ensure high-quality education as one of the most important conditions of formation and full implementation of the national economic potential.

\section{Conclusions}

The authors' system of development factors of educational environment has a number of advantages: 1. It fully meets all the principles of organization of the educational environment (the principle of fundamentalism, the principle of practical orientation and focus on the educational activity environment, the principle of unity in education, life and professional activity, the principle of personification).

2. It provides continuous and stable performance of the functions of the educational environment (the institutional coordination, functions, organizational activities, functions, information and analysis key features of forecasting).

Thus, the system of factors formulated and disclosed by the authors will help managers and professionals employed in this field of activity to make good, balanced decisions in the development of educational environment and, consequently, to achieve the most efficient results of educational institutions' activity in conditions of fully intensive educational process.

\section{References}

1. V.G. Bocharova, Social pedagogics (Moscow, 2004).

2. S.K. Bondyreva, Psychological and pedagogical problems of integration of educational space (Moscow, 2003)

3. N.M. Borytko, Teacher in the space of modern education (Volgograd, 2001)

4. A.N. Dzhurinsky, The development of education in the modern world (Moscow, 1999).

5. H.G. Gadamer, Truth and method: foundations of philosophical hermeneutics (Moscow, 1988)

6. I.A. Lipsky, L.E. Sikorska, Social pedagogy (Moscow, 2013).

7. D. Myers. Social psychology (Saint-Petersburg, 2013)

8. N.N. Pavelko, Psychology and pedagogy (Moscow, 2015)

9. M.M. Plotkin, Social education of schoolchildren (Moscow, 2003)

10. F.V. Sharipov, Pedagogical management (Moscow, 2014)

11. N.E. Shurkova, Theory of education (Moscow, 2003) 